DOI: $10.4274 /$ tjps.92408

\title{
Synthesis and Swelling Behavior of Sodium Alginate / Poly (vinyl alcohol) Hydrogels
}

\section{Sodyum Aljinat/ Polivinil Alkol Hidrojellerinin Sentezi ve Şişme Davranışları}

\begin{abstract}
Lachakkal Rudrappa SHIVAKUMARA ${ }^{1}$ and Thippaiah DEMAPPA ${ }^{1 *}$
${ }^{1}$ Department of Post Graduate Studies and Research in Polymer Science, University of Mysore, Sir.M.Visvesvaraya Post-Graduate Center, Tubinakere, Mandya, Karnataka, India- 571402.

${ }^{*}$ Corresponding author: Dr. T. Demappa. Email: tdemappa2003@yahoo.co.in
\end{abstract}

\section{ABSTRACT}

Objectives: Hydrogels are macromolecular networks able to absorb and release water/biological fluids in a reverse phase manner, in response to specific environmental stimuli. Such stimuli -sensitive behavior makes hydrogels interesting for the design of smart devices applicable to a variety of technological fields. They are able to absorb and retain $10-20 \%$ and upto 1000 times of water or biological fluids than their dry weight. The aim of this study is to extend the work in drug delivery in stomach at $\mathrm{pH} 2-2.2$.

Methods: The authors are synthesized sodium alginate/poly (vinyl alcohol) hydrogels. These hydrogels are characterized by FTIR, SEM, swelling properties of hydrogels in different $\mathrm{pH}$, in salts, different temperature, different acids and bases.

Results: The authors studied and reported that the swelling effects or variations such as effect of salts, acids, bases, temperature and $\mathrm{pH}$. The effect of crosslinking agent glutaraldehyde shows that the $8 \mathrm{~mL}$ glutaraldehyde has the highest swelling rate as compare to that of $10 \mathrm{~mL}$ and $12 \mathrm{~mL}$.

Conclusions: In this work authors studied the swelling degree in different acids and bases. We are concluded that the degree of swelling is decreased with increase in the concentration of the glutaraldehyde and also depending on the concentration of the acids. The swelling degree of PVA/SA hydrogels are 
gradually increased with increase in concentration of acids (low p H). The swelling of hydrogels decreases with increase of $\mathrm{pH}(>7)$ or at high alkaline. In the effect of salt solutions the swelling behavior is found to be in the order: $\mathrm{K}^{+}$ $>\mathrm{Na}^{+}>\mathrm{Ca}^{2+}>\mathrm{Mg}^{2+}$.

Key words: swelling, $\mathrm{P}^{\mathrm{H}}$, cross linking agent, buffer solution, Sodium alginate, PVA

\section{ÖZET}

Amaçlar: Hidrojeller, belirli çevresel uyaranlara yanıt olarak su / biyolojik sıvıları ters fazda emebilen ve serbest bırakabilen makromoleküler ağlardır. Bu tür uyaranlara duyarlı davranış, çeşitli teknolojik alanlara uygulanabilen akıllı cihazların tasarımı için hidrojelleri ilginç kılar. Kuru ağırlığından\% 10-20 ve 1000 veya daha fazla su veya biyolojik sıvıları emebilir ve tutabilirler. Bu çalışmanın amacı, ilacın 2-2,2.

Yöntemler: Yazarlar sentezlenmiş sodyum aljinat / poli (vinil alkol) hidrojellerdir. Bu hidrojeller FTIR, SEM, farklı pH'larda hidrojellerin şişme özellikleri, tuzlar, farklı sıcaklık, farklı asitler ve bazlar ile karakterize edilir.

Bulgular: Yazarlar, tuzların, asitlerin, bazların, sıcaklığın ve pH'ın etkisi gibi şişme etkilerini veya varyasyonlarını incelediler ve rapor ettiler. Çapraz bağlama maddesi glutaraldehitin etkisi, $8 \mathrm{~mL}$ glutaraldehidin, $10 \mathrm{~mL}$ ve $12 \mathrm{~mL}$ 'ninkiyle karşılaştırıldığında en yüksek şişme oranına sahip olduğunu göstermektedir.

Sonuçlar: Bu çalışmada yazarlar farklı asit ve bazlarda şişme derecesini incelemişlerdir. Glutaraldehit konsantrasyonundaki artışla ve aynı zamanda asit konsantrasyonuna bağlı olarak şişlik derecesinin azaldığı sonucuna varılmıştır. PVA / SA hidrojellerinin şişme derecesi, asit konsantrasyonundaki artışla (düşük $\mathrm{pH}$ ) kademeli olarak artmaktadır. Hidrojellerin şişmesi pH'ın (> 7) artmasıyla veya yüksek alkali ile azalır. Tuz çözeltilerinin etkisinde şişme davranışının sırasıyla: $\mathrm{K}+>\mathrm{Na}+>\mathrm{Ca} 2+>\mathrm{Mg} 2$ + olduğu bulunmuştur.

Anahtar kelimeler: şişme, PH, çapraz bağlama maddesi, tampon çözelti, sodyum aljinat, PVA 


\section{INTRODUCTION}

Hydrogels have been used in various chemical and biomedical applications in ophthalmology as contact lenses, surgical sutures, as well as in numerous other areas like agricultural applications.

Sodium alginate is an anionic co-polymer composed of 1 , 4-linked $\beta-D$ mannuronic (M- blocks) and $\alpha$ - L- guluronic acid (G- blocks), interspersed with the regions of alternating structure. Gel formation and three -dimensional network structures were occurs when divalent ions $\left(\mathrm{Ca}^{2+}, \mathrm{Ba}^{2+}, \mathrm{Fe}^{2+}, \mathrm{Si}^{2+}\right.$ etc. $)$ or trivalent ions $\left(\mathrm{Al}^{3+}\right.$, etc) cross-linking with G-blocks in the polymer chain. Such binding zones between G-blocks are often referred to as "egg boxes". These cross- linked ions that stabilize alginate chains forming a gel structure, with more freely movable chains that bind and entrap large quantities of water or biological fluids. The gel formation (gelification) processes is characterized by the eviction of water. ${ }^{1}$ The softer, more fragile and lower porosity gels are made of M-rich alginate groups. This is due to the lower binding strength between the polymer chains and to the higher flexibilities of the molecules. The gel formation process is highly dependent on diffusion of gel formation ions into polymer network. Visco- elasticity and transmittance of alginate structures are highly affected by the $M / G$ ratio. Alginic acid and its salts of sodium and calcium are being used in the medical, pharmaceutical, cosmetic and food industry because of its non-toxic and biocompatibility. ${ }^{2}$ The main advantages of hydrogels are that they possess a degree of flexibility very similar to that of natural tissues, due to their significant water content. The stimuli-sensitive behavior makes hydrogels interesting for the design of smart devices applicable to a variety of technological fields.

Hydrogels are in general, materials composed of three - dimensional hydrophilic polymer networks and water that fills the free spaces inside this network. Hydrogels are able to absorb and retain 10-20\% upto 1000 times of water or biological fluids than their dry weight. Hydrogels respond reversibly to slight changes of the properties of surrounding media; hence they are called as 
"intelligent materials." This ability is due to the hydrogels found many applications in industry and pharmacy, for example as controlled drug delivery systems. $^{3}$ The swelling and dehydration behavior is one of the most importances among other significant properties of hydrogels. ${ }^{4}$ Several applications of hydrogels such as drug delivery systems (drug slow release), a wound dressing, dental applications, transdermal implants, injectable polymers, contact lenses, super absorbents, and environmental sensitive hydrogels. ${ }^{5-9}$ Hydrogels are interacting with aqueous solutions and swelled to certain equilibrium and retain a significant proportion of water within their structure. ${ }^{10}$ Sodium alginate (SA) is a hydrophilic polysaccharide, natural polymer, composed of mannuronic acid unit. This compound has been used for a long time in various industries, such as agriculture, foods, medicines, textiles, cosmetics, printing, etc. SA is also used as a thickener, stabilizers, emulsifier or micro encapsulation. SA is also used in slow release drug delivery system, and fertilizer. ${ }^{11} \mathrm{SA}$ has a molecular structure similar with collagen, therefore it can make skin smooth, elastic and can recover wound, and it can be used as a natural alternative product for health care and cosmetics. ${ }^{12-14} \mathrm{SA}$ is biological origin, has good characteristics, such as biocompatible, or biodegradable and gel forming ability. Poly (vinyl alcohol) (PVA), is hydrophilic polymer, has a great interest to be used as a biomaterial because it has good biocompatible properties. It has chemical stability, high durability and high degree of swelling in water or biological fluids. PVA is non-toxic to viable cells, non- carcinogenic, has high biocompatibility, and has consistency similar to soft tissue, film forming with high mechanical strength and long -term temperature stability. Its 3dimensional network enable to facilitate diffusional exchange of nutrients and waste products with surrounding environment, it is used in various biomedical, pharmaceutical, biotechnology and other industrial fields. ${ }^{15-20}$ However, even though PVA is a biomaterial, but brittle in nature; therefore it needs to be blended with other polymer or by copolymerization, eg. with sodium alginate, to obtain a better property that can be used to encapsulate or entrap or to immobilize an enzyme or drug in micron or submicron (nano) size, to keep the constancy of its activity or to prevent activity decreases drastically. Hence make 
it work more effective and efficient compared to when it is in free condition. ${ }^{21-23}$ The cross linked alginate hydrogels have been used as a controlled release medium for drugs, ${ }^{24-28}$ Pesticides $^{29}$ superabsorbent filament fibers ${ }^{30}$ and flocculants. ${ }^{31}$

In the presence of an aqueous solution, the polymer chains absorb water and the association, dissociation and binding of various ions to polymer chains causes the hydrogel to swell. The shrinking and swelling properties of hydrogels are currently being exploited in a number of applications including control of micro fluidic flow, ${ }^{32}$ muscle-like actuators, ${ }^{33-34}$ filtration/separation ${ }^{35}$ and drug delivery. ${ }^{36-37}$ The structure and properties of hydrogels are similar to many biological tissues such as cartilage and the corneal stroma in the eye. ${ }^{38-39}$ Hydrogels are accomplished of undergoing large reversible deformation in response to changes in several environmental factors. ${ }^{40}$ For example, hydrogel size is sensitive to $\mathrm{pH}$, temperature, concentration of salts, and electric fields.

\section{EXPERIMENT}

\section{MATERIALS AND METHODS}

Materials

Sodium alginate, Poly (vinyl alcohol) molecular weight 1,25,000 and glutaraldehyde (25\%) was purchased from S.d. fine chem limited, Mumbai- 30, India. Hydrochloric acid, perchloric acid, sodium hydroxide and acetic acid were purchased from Reachem Laboratory chemicals private Itd, Chennai-600058, India. Calcium chloride, Magnesium chloride, sodium chloride, potassium chloride were purchased from E-Merk limited Mumbai -400018, India, and double distilled water were used throughout the experiment.

Methods

Preparation of Sodium alginate/ Poly (vinyl alcohol) hydrogels

$7 \mathrm{~g}$ of sodium alginate dissolved in $100 \mathrm{~mL}$ of water by constant stirring. $9 \mathrm{~g}$ of PVA dissolved in the same solution by stirring about $3 \mathrm{hr}$ at $80^{\circ} \mathrm{C}$ to $85^{\circ} \mathrm{C}$ and $12 \mathrm{~mL}$ of glutaraldehyde (25\%) is added to the same solution, this solution is kept under $80^{\circ} \mathrm{C}$ for $3 \mathrm{hr}$. After $3 \mathrm{hr}$ the obtained hydrogel is washed with distilled water and ethanol, to remove the excess monomer, cross -linking agent. After 2-3 times of washing the hydrogel are dried under $40^{\circ} \mathrm{C}$ in an oven. 
Likewise synthesized the different SA/PVA hydrogels by varying volume of glutaraldehyde (10 and $8 \mathrm{ml})$ are used for swelling studies.

\section{CHARACTRISATION}

Fourier-transform infrared spectroscopy

The FTIR spectra of the sodium alginate, PVA and the cross-linked hydrogel samples have been recorded in the range of 4000 to $500 \mathrm{~cm}^{-1}$ to provide the proof of hydrogels (Figure.1).

\section{Surface morphology of hydrogels}

The surface morphology of sodium alginate, PVA and glutaraldehyde crosslinking hydrogels were investigated by using scanning electron microscopy (SEM zeiss, LS15) (Figure.2).

\section{Swelling Behavior of hydrogels}

In the swelling behavior of hydrogels, authors also studied swelling ratio of the hydrogel sample was measured at different temperatures in different solvents by using gravimetric method. The pre weighed dry hydrogel samples were immersed in excessive different solutions and kept undisturbed by $24 \mathrm{hr}, 48 \mathrm{hr}$ and $72 \mathrm{hr}$ at different temperatures like room temperature, $30^{\circ} \mathrm{C}, 37^{\circ} \mathrm{C}$ and $40^{\circ} \mathrm{C}$ until the constant values is obtained. Degree of swelling rate can be calculated by the equation:

$$
\% \mathrm{DS}=\left(\mathrm{W}_{2}-\mathrm{W}_{1}\right) / \mathrm{W}_{1} \times 100
$$

$\% D S$ is the degree of swelling expressed in percentage, $W_{1}$ and $W_{2}$ are the masses of sample before and after swelling respectively (Figure.3 to 5) (Table1).

Swelling at various $\mathrm{pHs}$

We are prepared the solution to acidic, basic and neutral pHs by diluting of phosphate buffers $(\mathrm{pH} 3.2, \mathrm{pH} 7, \mathrm{pH} 2$ and $\mathrm{pH} 10)$ solutions at room temperature, $30^{\circ} \mathrm{C}, 37^{\circ} \mathrm{C}$ and $40^{\circ} \mathrm{C}$ temperatures. The $\mathrm{pH}$ values are checked by using $\mathrm{pH}$ meter. The dried hydrogel samples were used for the swelling measurement according to eqn (1) (Figure.6). 


\section{Swelling in salt solutions}

Swelling capacity of hydrogels was determined in the different salt solutions $\left(\mathrm{KCl}, \mathrm{NaCl}, \mathrm{CaCl}_{2}\right.$, and $\left.\mathrm{MgCl}_{2}\right)$ and also with various concentrations like 0.4, $0.6,0.8,1$, and $1.2 \mathrm{~N}$ according to the above method (Figure.7).

\section{RESULTS}

The authors reported the swelling effects of hydrogels on salts, acids, base, temperature and $\mathrm{pH} .8 \mathrm{~mL}$ of glutaraldehyde shows the highest swelling rate as compared to that of $10 \mathrm{~mL}$ and $12 \mathrm{~mL}$. Figure. 1 shows that FTIR spectra it deals with the molecular interaction between sodium alginate and PVA. Surface morphology of hydrogels was studied by using scanning electron microscopy (SEM zeiss, LS15) in figure 2, figure 3 to 5 and table 1 represent swelling behaviour of hydrogels at different temperature i.e; $30^{\circ} \mathrm{C}, 37^{\circ} \mathrm{C}, 40^{\circ} \mathrm{C}$ and room temperature with different salts. Figure 5 represent behaviour of hydrogels at different $\mathrm{pH}$.

\section{DISCUSSION}

Fourier transformed infrared spectral analysis

Figure 1 represents the FTIR spectra, characterized the molecular interaction of sodium alginate and Poly (vinyl alcohol) hydrogels. The FTIR spectra of SA shows the characteristic absorption peak at $3270.47 \mathrm{~cm}^{-1}$ is for hydroxyl groups $(-\mathrm{OH})$. The asymmetric and symmetric stretching vibration of carboxylic group (COO-) is found to be at 1597.36 and $1412 \mathrm{~cm}^{-1}$ respectively. ${ }^{41-42}$ The peak at $2925.38 \mathrm{~cm}^{-1}$ represents for $\mathrm{C}-\mathrm{H}$ alkyl stretching bond. ${ }^{43}$ An absorption peak around $2919.05 \mathrm{~cm}^{-1}$ shows the characteristic spectra of PVA. This peak is arising from the $\mathrm{C}-\mathrm{H}$ stretching at 1570 to $1420 \mathrm{~cm}^{-1}$ assigned for $\mathrm{CH}_{2}$ (vinyl group), the sharp absorption peak at $1150-1050 \mathrm{~cm}^{-1}$ is used for indication of PVA. ${ }^{44}$ In addition, it was found that the peak at $1549-1453 \mathrm{~cm}^{-1}$ is stretching band for $\mathrm{CH}_{2}$ group. This band is also found in pure PVA and cross linked SA/PVA hydrogels. The decreasing in wave number of carbonyl peak from 1652.14 to $1635.24 \mathrm{~cm}^{-1}$ is for the cross-linking of SA/PVA hydrogels. Cross linking of glutaraldehyde is takes place at 2863 to $2750 \mathrm{~cm}^{-1}$. 
Scanning electron microscopy (SEM) images

Scanning electron microscopy (SEM) describes the surface morphology of SA/PVA hydrogels in figure 2. According to the SEM images (Figure 2a), the pure sodium alginate shows a very smooth surface which is about devoid of any surface feature ${ }^{44}$. In figure $2 b$ SEM images of pure PVA shows a very smooth, uniform and non-porous surface structure, which may be attributed to the crystallization of PVA. ${ }^{45}$ However, the addition of SA into PVA hydrogel in different portions provides very tiny pores at surface, these pores decreases with increase of glutaraldehyde concentration (Fig $2 \mathrm{c}$ to $2 \mathrm{e}$ ).

\section{Effect of $\mathrm{pH}$ on Swelling of Hydrogels}

The sensitivity of the hydrogels was measured from $\mathrm{pH} 2-\mathrm{pH} 10$. No additional ions (through buffer solutions) were added to medium for setting $\mathrm{pH}$ because absorbency of an absorbent is strongly affected by ionic strength. Therefore stock $\mathrm{HCl}(\mathrm{pH} 1.0)$ and $\mathrm{NaOH}(\mathrm{pH} 10.0)$ solutions were diluted with distilled water to reach preferred acidic or basic pHs respectively. In table 2, figure 6 , the swelling capacity of hydrogel at $\mathrm{pH} 2$ can be accredited high repulsion of anion-anion carboxylic (COO-) groups. At basic conditions $(\mathrm{pH} \geq 7)$, the most of the carboxylate groups are protonated and the low swelling values of hydrogels can be attributed the presence of non-ionic hydrophilic $-\mathrm{OH}$, and - $\mathrm{COOH}$ groups in the PVA and alginate back bones respectively. The swelling capacity is decreased with further increase of $\mathrm{pH}(\mathrm{pH} 10$ or $\mathrm{pH}>7)$. Again the swelling loss is due to the counter ions, i.e $\mathrm{Na}+$, that shield the charge of the carboxylate anions and prevent efficient anion- anion repulsion. As a result, a remarkable decrease in equilibrium swelling is observed.

pH Dependence of Swelling rate of water

The swelling rate was decreased with increasing from $\mathrm{pH} 2-10$; it was evident from the data given. The negatively charged ionic back bone of PVA and SA are more expanded because of protonation of carboxylic groups is negatively charged. This expanded form makes for easy diffusion of water molecules into the hydrogel network. On the converse, the hydroxyl groups are mostly in the 
protonated form, and show less polar character on $\mathrm{pH} \geq 7$. And therefore, results in the polymer with lower affinity to water. Thus, hydrogels are less expanded on $\mathrm{pH} \geq 7$. The increased in swelling ratio are responsible for theory of electrostatic repulsion between carboxylic ions in the polymer chains and ionic present in the $\mathrm{pH}$ solution and the ionic osmotic pressure generated from mobile counter ions to charged ion in the network. Thus, dilute the charge density of the hydrogel, because of PVA is not ionic in character (Table 2). Figure.6 show the Swelling studies of phosphate buffered $\mathrm{pH}$ solutions, the glutaraldehyde cross-linked PVA/SA samples show gradual increase (in swelling degree in the $\mathrm{pH} 2$ and 3.2) followed by decreased in swelling degree in the $\mathrm{pH} 7$ and 10 at different temperatures $\left(25^{\circ} \mathrm{C}, 30^{\circ} \mathrm{C}, 37^{\circ} \mathrm{C}\right)$. In this studies $8 \%$ glutaraldehyde cross linked hydrogel having high swelling degree as comparing to the $10 \%$ and $12 \%$ glutaraldehyde cross- linked hydrogels.

\section{Effect of Temperature on Swelling of Hydrogels}

It is obvious from the Figure 6 that the temperature leading to hydrogel with the highest absorbency is found to be around $37^{\circ} \mathrm{C}$. The swelling capacity of hydrogel was decreased with increasing temperature above the $37^{\circ} \mathrm{C}$. The increase in swelling rate values is dependent on kinetic energy of the polysaccharide chains which led to lower soluble content of the hydrogel as well as increasing the concentration of glutaraldehyde diffusion rate of SA and PVA back bone. The higher reaction temperature proves the results from higher reactant movement and effective collision. The temperature about $37^{\circ} \mathrm{C}$, the possible "thermal cross linking" reaction to polysaccharide backbones may act as a major role to lead low-swelling hydrogels. In addition, the swelling loss may be related the increasing of cross linked bond formation of completion of the ester and ether formations by further reaction to the possible mono-ester species with another polysaccharides chain (scheme1).

\section{Effect of Salt solution to Hydrogels}

Hydrogels are considered as poly electrolytes suggest that their porosity should decrease as ionic strength increases. SA/PVA hydrogels with various chloride salt solutions are appreciably reduced in swelling compared to that of measured 
in de-ionized water. This results from a charge screening effect of the additional cations causing an anion-anion electrostatic repulsion, which leads to decreased osmotic pressure difference between the polymer network and the external solution. As a given ionic strength, $\mathrm{Mg}^{2+}$ and $\mathrm{Ca}^{2+}$ contribute more charge than mono valent cations like $\mathrm{Na}^{+}$and $\mathrm{K}^{+}$and induce a bigger drop in intermolecular repulsion and increased interaction between molecules, which in turn, cause to a large extent of the hydrogel collapse. In addition, $\mathrm{Mg}^{2+}$ and $\mathrm{Ca}^{2+}$ can chelate carboxylic group, leading to a compact network and causing further shrinking from the hydrogel, on the other hand, we also find that the smaller the radius of atom of some valent mono atomic cation, the more the water absorption capacity if different cations was $\mathrm{K}^{+}>\mathrm{Na}^{+}>\mathrm{Ca}^{2+}>\mathrm{Mg}^{2+} .46$ (Table 3) \& (Figure 7)

\section{CONCLUSION}

In this work authors studied the swelling degree in different acids and bases. By this study we are concluded that the degree of swelling is decreased with increase in the concentration of the glutaraldehyde and also depending on the concentration of the acids. Here swelling degree of PVA/SA hydrogels has gradually increased with increase in the concentration of acids. The aldehyde groups are covalently bonded with the $\mathrm{COO}$ - and $\mathrm{OH}$ - groups of PVA/SA and consequently the swelling degree is significantly reduced. In different concentration of different salts the swelling rates are found to be decreased with increasing concentration of salts. The swelling rate is in the order of $\mathrm{K}^{+}>\mathrm{Na}^{+}>$ $\mathrm{Ca}^{2+}>\mathrm{Mg}^{2+}$.

\section{Acknowledgments}

The authors are thankful to the institution of excellence (IOE) for the FTIR and SEM analysis help and have been greatly acknowledged.

\section{Further extension of the work}

This swelling study is to be extended for biomedical and agricultural applications such as drug delivery and controlled release fertilizers. ${ }^{46}$ 


\section{REFERENCES}

1. Serp D, Mueller M, Stockar U, Marison IW. Low -temperature electron microscopy for the study of polysaccharide ultra structures in hydrogels. Biotechnology and Bioengineering. 2002;79:253-259.

2. Gombotz WR, Wee SW. Protein release from alginate matrices. Adv Drug Deliv Rev. 1998;31:pp267-285.

3. Dumitriu S, Polysaccharides as Biomaterials in Dumitriu, S (ed). Polymeric Biomaterials. CRC Press, Boca Raton. 2001;pp1-62.

4. Gemienhart RA, Guoch, Fast swelling hydrogel systems. in: Yui N, Mrsny RJ, Park K, (eds). Reflexive Polymers and Hydrogels. CRC Press, New York. 2004;pp245-258.

5. Rosiak JM, Yoshii, F. Hydrogels and medical applications. Nucl. Instr. Meth. Phys Rev. 1999;151:56-64.

6. Silva GS, Fernadez LRV, Higa OZ, Vitolo M, De Queiroz ASA. Alginate -Poly (vinyl alcohol) core -shell microspheres for lipase - immobilization. Cebecimat, XVI congreso Brasileiro de Engenhariae Ciencia dos Materials. Porto Alegre RS de 28 de novembroa 02 de dezembro de. 2004;15p.

7. Abbas AA, Lee SY, Selvaratnam L, Yusof N, Kamaru T. Porous PVA- chitosan based hydrogels as an extracellular matrix scaffold for cartilage regeneration. European cells and materials 2008;16 (suppl.2):50.

8. Ustundag GC, Karaca E, Ozbek S, Cavusoglu I. Cavusoglu, In vivo evaluation of electrospun Poly(vinyl alcohol) / sodium alginate nanofibrous mat a wound dressing, Tekstil ve konveksiyon. 2010;4:290-298.

9. Sariri R, Physicochemical characteristics and Biomedical applications of hydrogel. A review. J. Phys.Theor. chem. IAU Iran. 2011;8(3):217-231.

10. Tombs MP, Harding SE. An Introduction to Polysaccharide Biotechnology. Taylor and Francis, UK. 1999;183p.

11. Cunha AG, Gandini A. Turning polysaccharides into hydrophobic materials: a critical review. Part 2. Hemicellulose, chitin/chitosan, starch, pectin and alginates. Cellulose. 2001;17(6):1045-1065.

12. Cha DS, Choi JH, Chinnan MS, Park HJ. Antimicrobial film based Na-alginate and K- carrageenan Lebensmittel-Wissenschaft und- Technologie. 2002;35(8): 
715- 719 .

13. Boninsegna S, Dal Toso R, Dal Moute R, Carturan G. Alginate microspheres loaded with animal cells and coated by a siliceous layer. Journal of Sol-Gel Science and Technology. 2003;26(1-3):1151-1157.

14. Lee KY, Mooney DJ. Hydrogels for tissue engineering. Chem Rev. 2001;101: 1869- 1880.

15. Hoffman AS. Hydrogels for biomaterial applications. Adv Drug Deliv. Rev. 2002;43:3-12.

16. Bahrami SB, Kordestani SS, Mirzadeh H, Mansoori P. Poly (vinyl alcohol) Chitosan blends: preparation, mechanical and physical properties. Iranian Polymer Journal. 2003;12(2):139-146.

17. Nam SY, Nho YC, Hong SH, Chae GT, Jang HS, Suh TS, Ahn WS, Ryu KE, Chun HJ. Evaluation of poly (vinyl alcohol)/alginate hydrogels cross-linked by $\gamma$-ray irradiation technique. Macromolecular Research. 2004;12(2):219-224.

18. Mishra S, Bajpai R, Katare R, Bajpai AK. Radiation induced cross linking effect on semi -interpenetrating polymer networks of poly (vinyl alcohol). eXPRESS Polymer Letters. 2007;I (7):407- 415.

19. Zain NAM, Suhaimi MS, Idris A. Development and modification of PVAalginate as suitable immobilization matrix. Process Biochemistry. 2011;46:21222129.

20. Wu KYA. Wisecarver, K. D. Cell immobilization using PVA crosslinked with boric acid. Biotech and Bioeng. 1992;39:447-449.

21. Silva GS, Fernandez LRV, Higa OZ, Vitolo M, De Queiroz ASA. Alginatepoly (vinyl alcohol) core -shell microspheres for lipase - immobilization. Cebecimat, XVI congreso Brasileiro de Engenhariae Cincia dos Materials. Porto Alegre- R.S de 28 de novembro a 02 de dezembro de. 2004; 15p.

22. Dave R, Madamwar D. Polymer of poly (vinyl alcohol)- boric acid for esterification in organic media. Indian Journal of Biotechnology. 2006;5(suppl.): 368-372.

23. Kulkarni AR, Soppimath KS, Aminabhavi TM. Pharm. Acta Helv. 1999;74:29.

24. Ostberg T, Vesterhus L, Graffner C. Int.J. Pharm. 1993;97:183.

25. Pillay V, Dangor DM, Govender T, Moopanar KR, Hurbans N. Drug.Delivery 
1998;5:35.

26. Pillay V, Dangor DM, Govender T, Moopanar KR, Hurbans N. J.Micro encapsulation. 1998;15:215.

27. Pillay R, Fassihi. J.Controlled Release. 1999;59:229.

28. Kulkarni AR, Soppimath TM, Aminabhavi AM, Dave MH, Mehta. J.of Controlled Release. 2000; 63: 97.

29. Kim YJ, Yoon KJ, Ko SW. J. Appl.Polym.Sci. 2000;78:1997.

30. Tripathy T, Pandey SR, Karmakar NC, Bhagat RP, Singh RP. Eur.Polym.J. 1999; $35: 2057$.

31. Beebe DJ, Moore J, Bauer JM, Liu Q, Yu RH, Devadoss C, Jo BH. "Functional hydrogel structures for autonomous flaw control inside micro- fluidic channels". Nature Apr 2000;Vol. 404.

32. Shahinpoor M. J. "Micro-elecctro - mechanics of ionic polymer gels as Electrically controllable artificial muscles”. Intell.Mater.Syst.Struct.1995;Vol. 6: Pp 307- 314 .

33. Brock D, Lee WJ. "A dynamic model of a linear actuator based on polymer Hydrogels". Intel Mater.System. struct. 1994;Vol.5:pp.764-771.

34. Helfferich F. Ion exchange, New York: McGraw-Hill, 1962;5.

35. Grodzinsky AJ, Grinshaw PE. "Elctrically and Chemically controlled hydrogels, for drug delivery”. Pulsed and self- Regulated Drug delivery. 1990;pp 47- 64.

36. Peppas NA, Brannon-Peppas L. "Solute and Penetrant diffusion in swellable polymers. IX. The mechanism of drug release from $\mathrm{pH}-$ sensitive swelling controlled systems" J.Control. Release. 1989;pp:267-274.

37. Eisenberg SR. The kinetics of chemically induced non equilibrium swelling of articular cartilage and Corneal stroma. J. Biomed. Eng. 1987;Vol. 109:Pp. 7989.

38. Myers ER, Lai WM, Mow VC. "A continuum theory and an experiment for the Ion-induced swelling behavior of articular cartilage”. J. Biomed.Eng. 1984;pp: $151-158$.

39. Okano K, Bac YH, Kim SW. "Temperature responsive controlled drug Delivery." Pulsed and self- Regulated Drug Delivery Pulsed and self- Regulated Drug Delivery. 1990;pp:17- 46. 
40. Kim JO, Park JK, Kim JH, Jin SG, Yonga CS, Li Dx, Choi HG. Development of Poly (vinyl alcohol) - sodium alginate gel-matrix -based wound dressing system Containing Nitrofurazone. Int.J.Pharm. 2008;359:79-86.

41. Chhatri A, Bajpai AK, Shandhu SS, Jain N, Biswas, J. Cryogenic fabrication of salvon loaded macroporous blends of alginate and Poly(vinyl alcohol) (PVA). Swelling, deswelling and antibacterial behaviors. Cabohydr.Polym. 2011;83: $876-882$.

42. Mansur HS, Orefice RL, Mansur AAP. Characterization of Poly (vinyl alcohol)/ Poly (ethylene glycol) hydrogels and PVA - derived hybrids by small -angle XRay Scattering and FTIR spectroscopy. Polymer 2004;45 (21):7193-7202.

43. Sonali karnik M, udayabhanu jammalamadaka K, Karthik, Tappa Rebecca K, Giorno,David, Mills,Heliyon. Permance evalution of nanoclay enriched antimicrobial hydrogels for biomedical application. Heliyon 2016;Feb 2(2):e00072.

44. Elbadawy A, Kamouna S, El-Refaie, Kenawy b, Tamer M, Tamer C, Mahmoud A, El- Meligy b, Mohamed S, Mohy Eldin. Poly (vinyl alcohol)-alginate physically crosslinked hydrogel membranes for wound dressing applications: Characterization and bio-evaluation. Arabian Journal of Chemistry. 2015;8:38-47.

45. Zho Y, Su HJ, Fang L, Tan TW. Polymer. 2005;46:5368.

46. Amany I, Raafat, Magda B, El- Arnaouty. Radiation synthesis of superabsorbent CMC based hydrogels for agriculture applications. Nuclear instrument and methods in physics research section B: Beam interaction with materials and atoms. volume $283,15 J u l y ~ 2012$,pages 71-76. 
Table 1. Data's of Swelling rate of $8 \mathrm{~mL}$ glutaraldehyde, $10 \mathrm{~mL}$ glutaraldehyde and $12 \mathrm{~mL}$ glutaradehyde crosslinked hydrogels at $37^{\circ} \mathrm{C}$.

\begin{tabular}{|c|c|c|c|c|c|c|c|c|c|}
\hline \multirow[t]{2}{*}{ Con.c } & \multicolumn{3}{|c|}{$8 \mathrm{ml}$ glutaraldehyde } & \multicolumn{3}{|c|}{$10 \mathrm{ml}$ glutaraldehyde } & \multicolumn{3}{|c|}{$12 \mathrm{ml}$ gltaraldehyde } \\
\hline & $24 \mathrm{hr}$ & $48 \mathrm{hr}$ & $72 \mathrm{hr}$ & $24 \mathrm{hr}$ & $48 \mathrm{hr}$ & $72 \mathrm{hr}$ & $24 \mathrm{hr}$ & $48 \mathrm{hr}$ & $72 \mathrm{hr}$ \\
\hline $1 \mathrm{~N} \mathrm{CH}_{3} \mathrm{COOH}$ & 54.46 & 107.56 & 109.85 & 45.78 & 63.39 & 66.32 & 14.02 & 32.15 & 33.85 \\
\hline $2 \mathrm{~N} \mathrm{CH}_{3} \mathrm{COOH}$ & 252.3 & 288.74 & 348.05 & 51.23 & 69.34 & 70.15 & 14.71 & 32.79 & 34.21 \\
\hline $4 \mathrm{~N} \mathrm{CH}_{3} \mathrm{COOH}$ & 260.74 & 297.36 & 348.05 & 60.19 & 72.43 & 74.12 & 14.97 & 33.56 & 34.69 \\
\hline $6 \mathrm{~N} \mathrm{CH}_{3} \mathrm{COOH}$ & 266.08 & 300.42 & 303.35 & 63.48 & 74.12 & 77.06 & 15.09 & 33.81 & 34.8 \\
\hline $1 \mathrm{~N} \mathrm{HCl}$ & 70.16 & 229.4 & 240.17 & 61.19 & 67.93 & 71.72 & 12.43 & 23.79 & 25.77 \\
\hline $2 \mathrm{~N} \mathrm{HCl}$ & 495.5 & 662.89 & 771.3 & 88.49 & 112.83 & 115.98 & 19.19 & 28.07 & 32.08 \\
\hline $4 \mathrm{~N} \mathrm{HCl}$ & 673.93 & 918.08 & 938.37 & 126.25 & 133.29 & 137.58 & 28.18 & 35.93 & 40.34 \\
\hline $6 \mathrm{~N} \mathrm{HCl}$ & 679.83 & 937.44 & 973.77 & 129.18 & 133.7 & 139.0 & 55.44 & 69.88 & 71.86 \\
\hline $1 \mathrm{~N} \mathrm{HClO}_{4}$ & 124.47 & 169.92 & 173.65 & 132.12 & 133.5 & 137.56 & 11.9 & 10.69 & 11.79 \\
\hline $2 \mathrm{~N} \mathrm{HClO}_{4}$ & 179.23 & 209.78 & 239.01 & 166.09 & 207.7 & 209.05 & 17.74 & 22.18 & 27.19 \\
\hline $4 \mathrm{~N} \mathrm{HClO}_{4}$ & 890.19 & 957.01 & 976.08 & 260.01 & 268.59 & 277.18 & 19.21 & 23.29 & 31.07 \\
\hline $6 \mathrm{~N} \mathrm{HClO}_{4}$ & 892.27 & 968.14 & 973.0 & 263.72 & 268.72 & 278.29 & 23.41 & 32.17 & 34.02 \\
\hline $1 \mathrm{~N} \mathrm{NaOH}$ & 47.26 & 47.02 & 46.24 & 32.87 & 29.4 & 27.64 & 34.97 & 22.83 & 19.31 \\
\hline $2 \mathrm{~N} \mathrm{NaOH}$ & 50.75 & 50.13 & 49.08 & 130.31 & 105.43 & 101.92 & 35.21 & 29.01 & 29.09 \\
\hline $4 \mathrm{~N} \mathrm{NaOH}$ & 53.24 & 53.02 & 52.86 & 134.04 & 107.47 & 104.36 & 39.93 & 38.14 & 36.69 \\
\hline $6 \mathrm{~N} \mathrm{NaOH}$ & 55.23 & 54.71 & 53.01 & 135.6 & 104.25 & 102.1 & 41.74 & 37.25 & 36.07 \\
\hline
\end{tabular}


Table 2. Data's of Swelling studies of hydrogels in different $\mathrm{pH}$ solution at $37^{\circ} \mathrm{C}$.

\begin{tabular}{|c|c|c|c|c|c|c|c|c|c|}
\hline & \multicolumn{3}{|c|}{$8 \mathrm{ml}$ glutaraldehyde } & \multicolumn{3}{|c|}{ 10ml glutaradehyde } & \multicolumn{3}{|c|}{$12 \mathrm{ml}$ glutaraldehyde } \\
\hline & $24 \mathrm{hr}$ & $48 \mathrm{hr}$ & $72 \mathrm{hr}$ & $24 \mathrm{hr}$ & $48 \mathrm{hr}$ & $72 \mathrm{hr}$ & $24 \mathrm{hr}$ & $48 \mathrm{hr}$ & $72 \mathrm{hr}$ \\
\hline $\mathrm{pH} 2$ & 120.2 & 121.56 & 122.01 & 75.65 & 76.92 & 77.15 & 75.19 & 76.08 & 77.33 \\
\hline $\mathrm{pH} 3.2$ & 109.2 & 113.2 & 116.07 & 72.01 & 74.1 & 76.12 & 73.24 & 74.19 & 75.28 \\
\hline $\mathrm{pH} 7$ & 70.37 & 77.78 & 83.34 & 67.92 & 68.12 & 69.12 & 66.27 & 67.19 & 68. \\
\hline $\mathrm{pH} 10$ & 69.24 & 71.34 & 73.45 & 65.26 & 66.74 & 67.05 & 65.48 & 66.47 & 67.1 \\
\hline
\end{tabular}

Table 3. Data's of swelling studies of hydrogels in different salt solutions.

\begin{tabular}{|c|c|c|c|c|c|c|c|c|}
\hline \multirow[t]{2}{*}{ Con.c } & \multicolumn{4}{|l|}{$12 \mathrm{hr}$} & \multicolumn{4}{|l|}{$24 \mathrm{hr}$} \\
\hline & $\mathrm{KCl}$ & $\mathrm{NaCl}$ & $\mathrm{CaCl}_{2}$ & $\mathrm{MgCl}_{2}$ & $\mathrm{KCl}$ & $\mathrm{NaCl}$ & $\mathrm{CaCl}_{2}$ & $\mathrm{MgCl}_{2}$ \\
\hline 0.4 & 370.42 & 340.16 & 310.72 & 288.02 & 377.72 & 345.45 & 314.7 & 293.6 \\
\hline 0.6 & 230.17 & 200.36 & 190.64 & 165 & 235.46 & 203.8 & 193.4 & 167.9 \\
\hline 0.8 & 200.23 & 185.34 & 140.39 & 117.79 & 205.0 & 188.1 & 142.9 & 119.2 \\
\hline 1.0 & 120.14 & 80.08 & 70.06 & 67.58 & 124.19 & 82.5 & 72.01 & 69.1 \\
\hline 1.2 & 75.09 & 60.63 & 40.46 & 35.96 & 78.20 & 62.04 & 42.02 & 37.4 \\
\hline
\end{tabular}




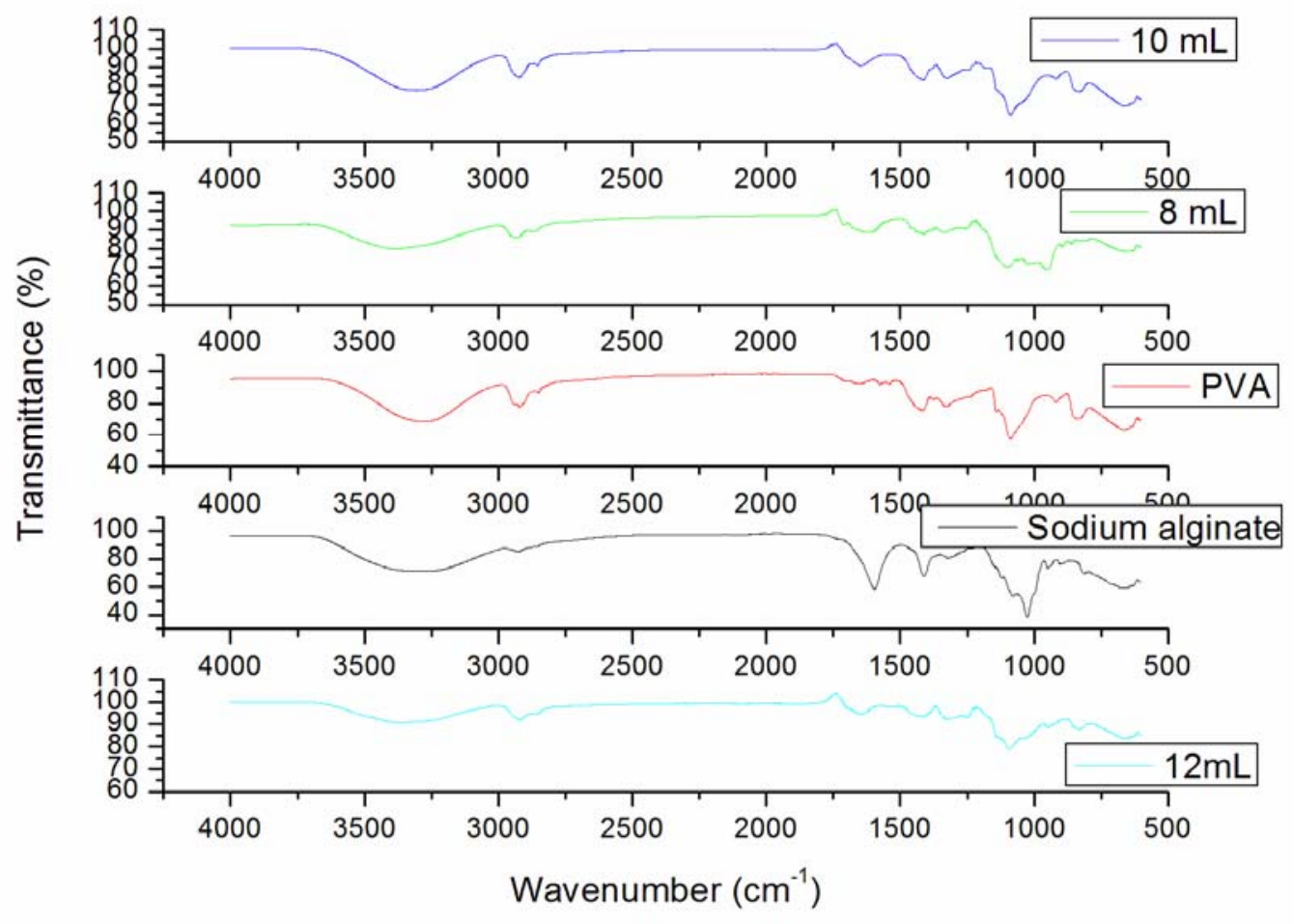

Figure 1. FTIR spectra of pure SA, PVA, $12 \%$ glutaraldehyde cross linked, $10 \%$ glutaraldehyde cross- linked and $8 \%$ glutaraldehyde cross-linked hydrogels. 


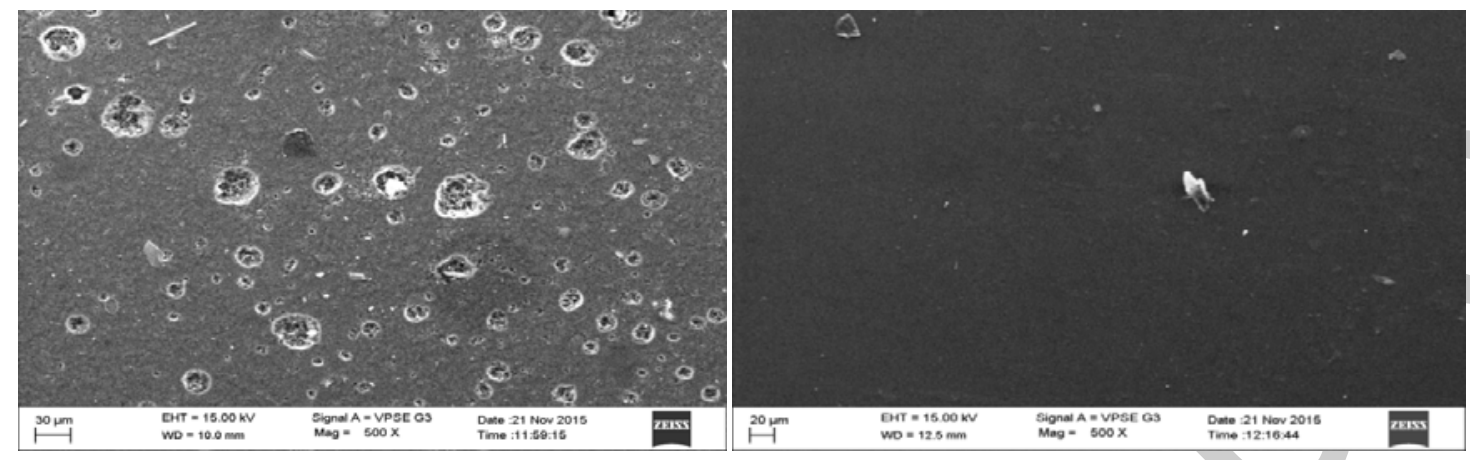

(a)

(b)

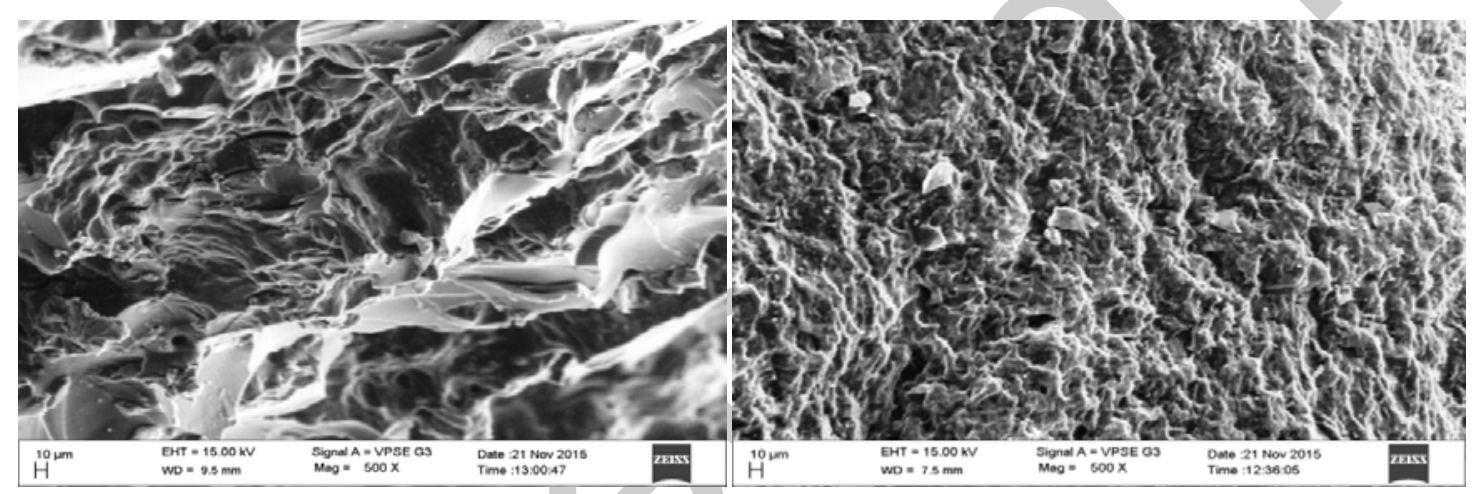

(c)

(d)

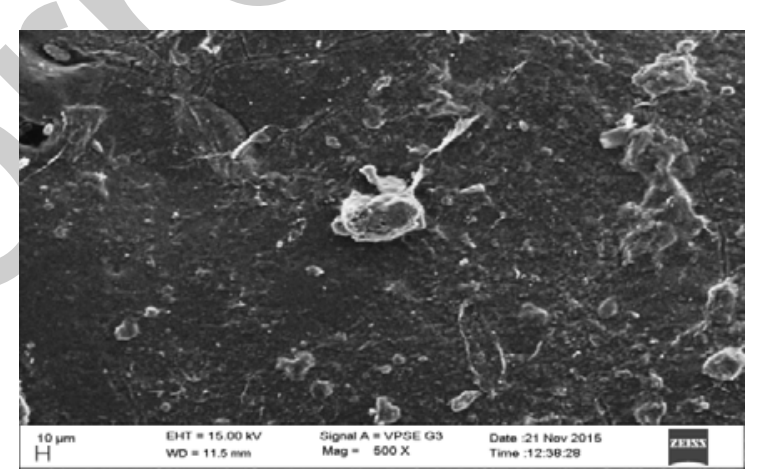

(e)

Figure 2. SEM images of (a) Pure sodium alginate, (b) Pure PVA (c) 8 ml glutaraldehyde cross linked SA/PVA hydrogel (d) $10 \mathrm{ml}$ glutaraldehyde cross linked SA/PVA hydrogels (e) $12 \mathrm{ml}$ glutaraldehyde cross linked SA/PVA hydrogels. 


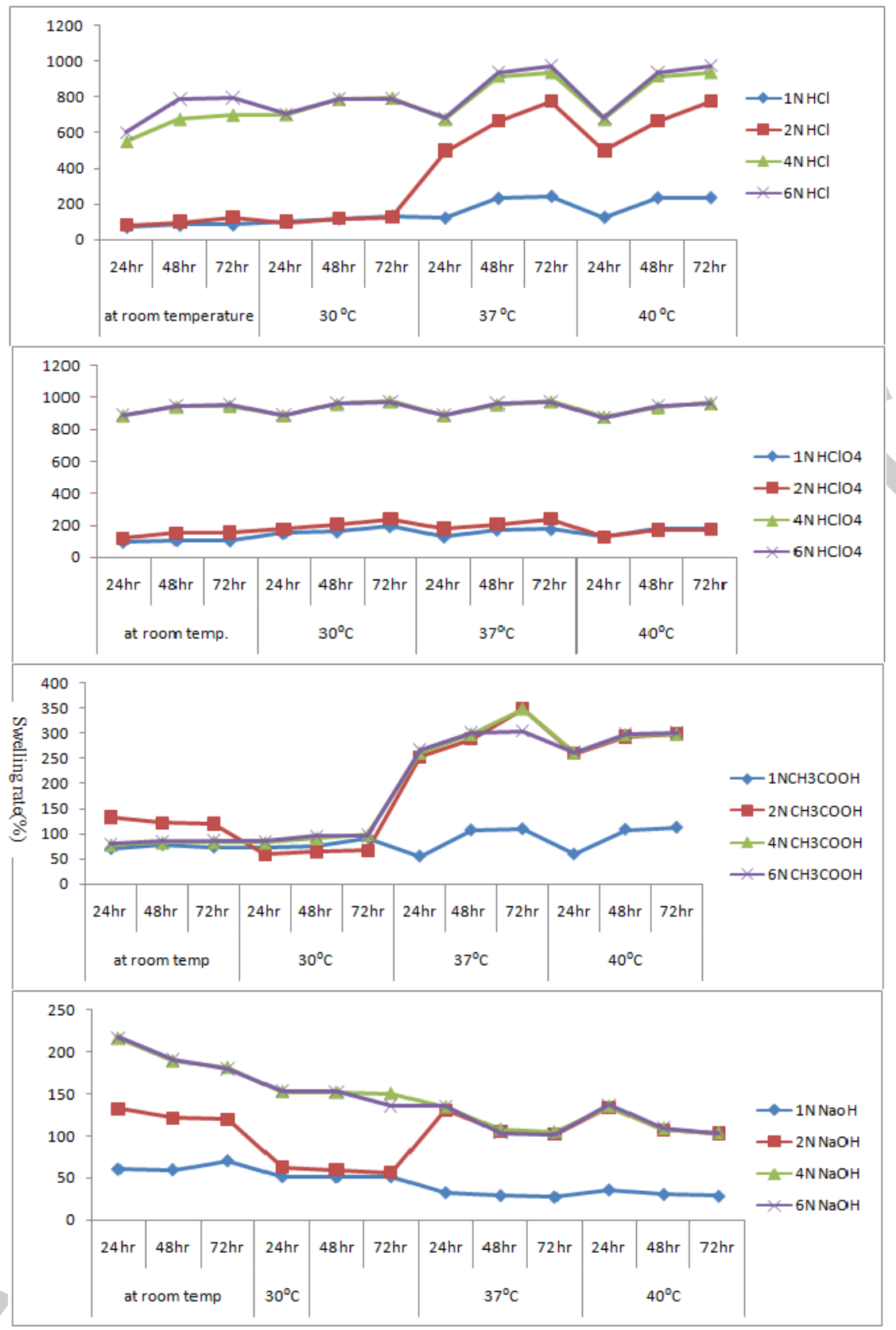

Figure 3. Swelling rate of $8 \mathrm{ml}$ glutaraldehyde crosslinking hydrogels. 


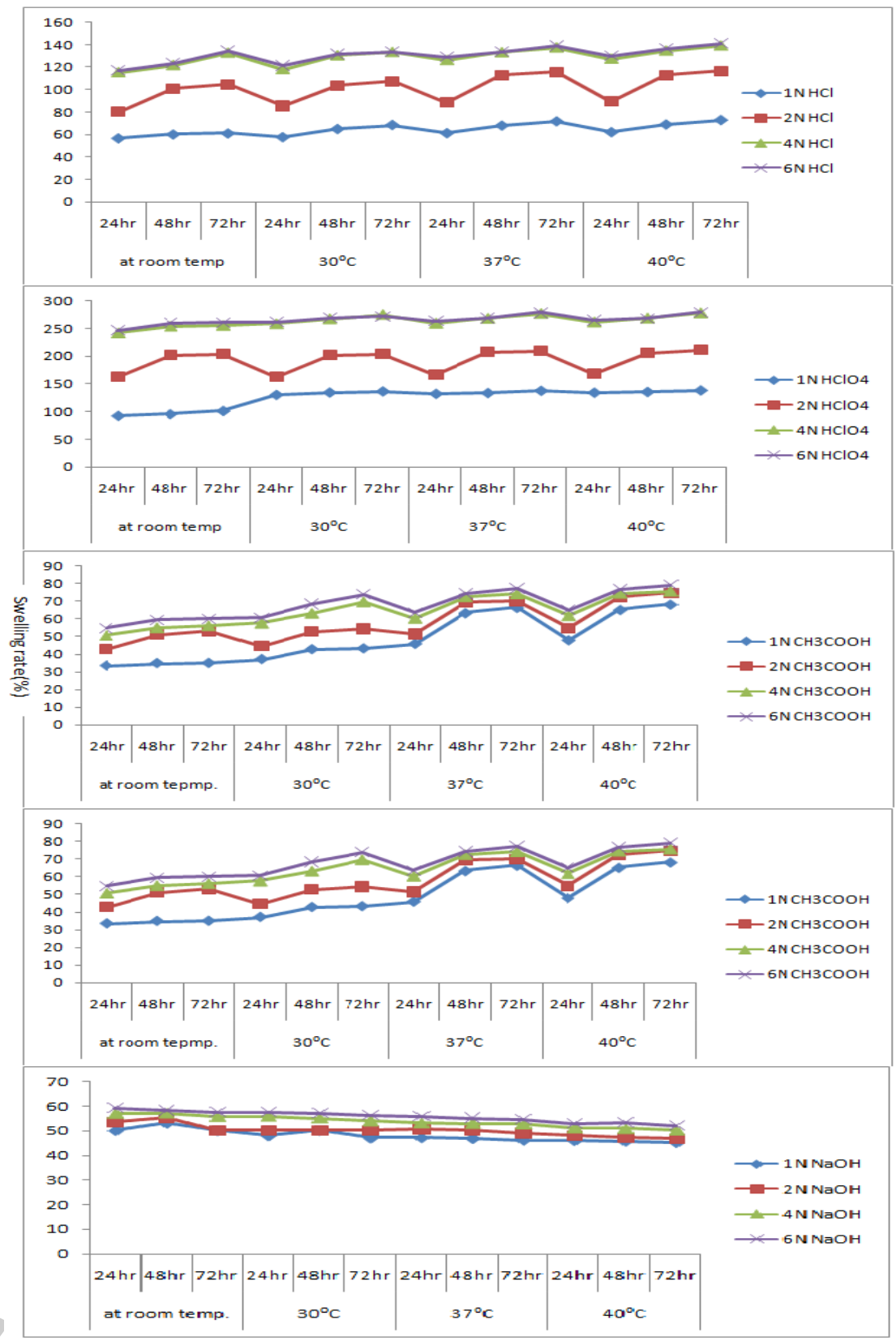

Figure 4. Swelling rate of $10 \mathrm{ml}$ glutaraldehyde crosslinked hydrogels. 


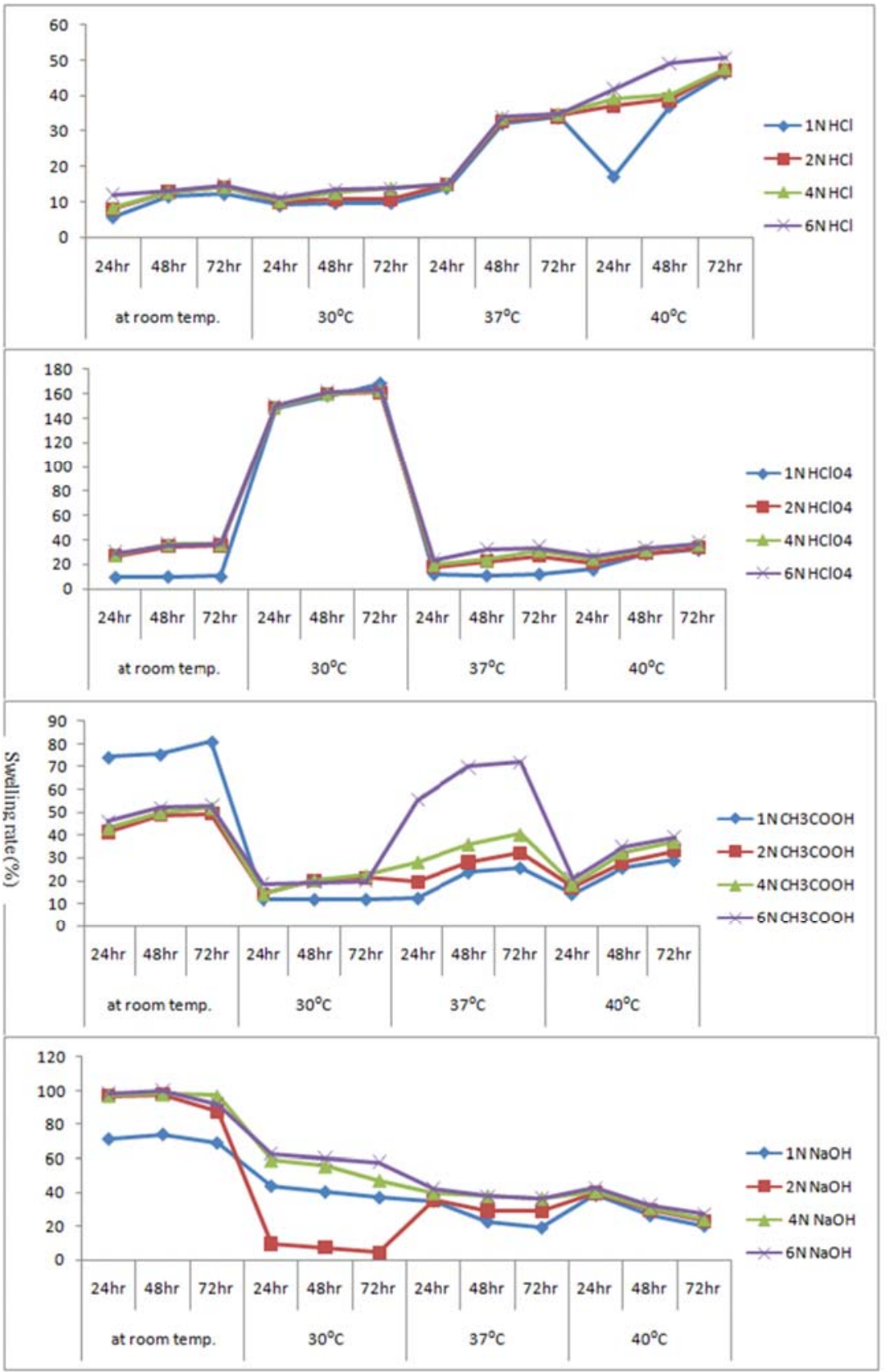

Figure 5. Swelling rate of $12 \mathrm{ml}$ glutaraldehyde crosslinked hydrogels. 


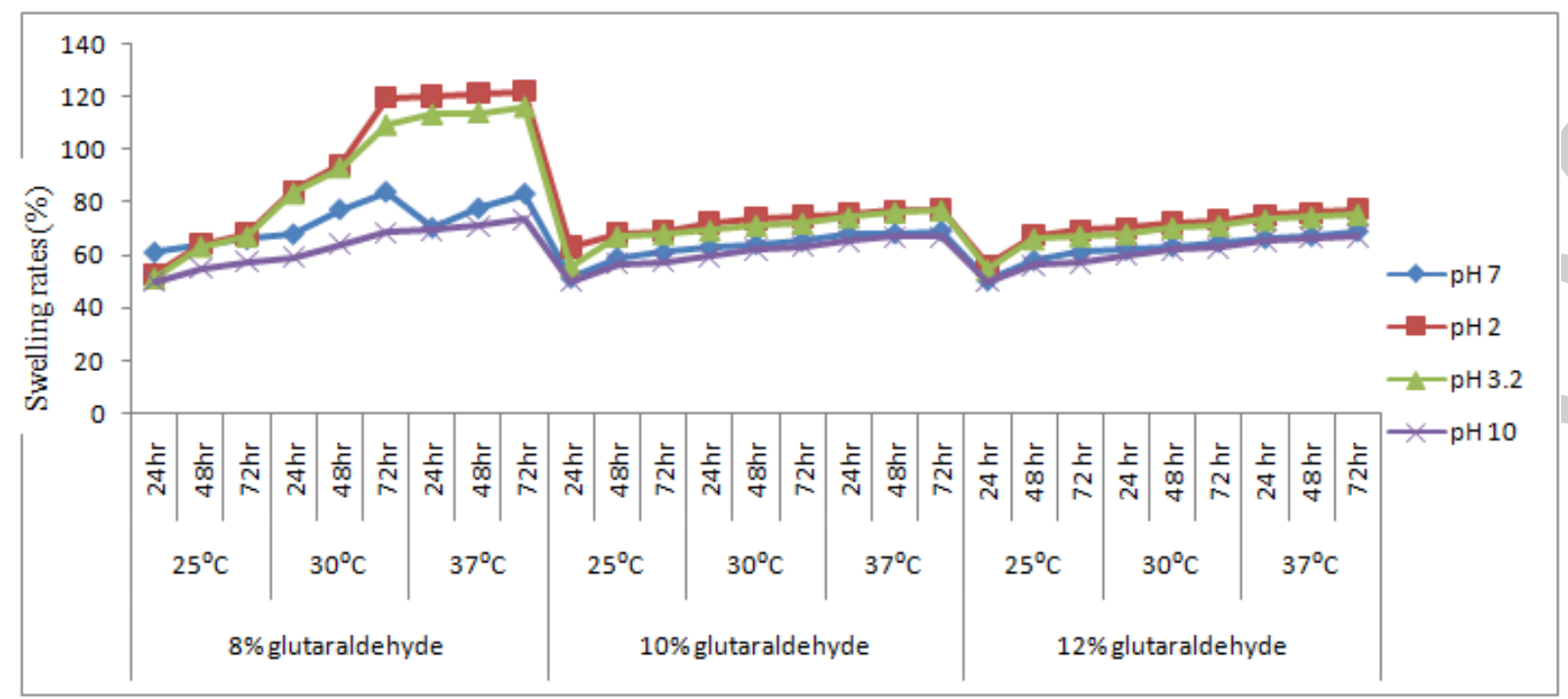

Figure 6. Swelling studies of hydrogels at different $\mathrm{pH}$ of phosphate buffer solutions.

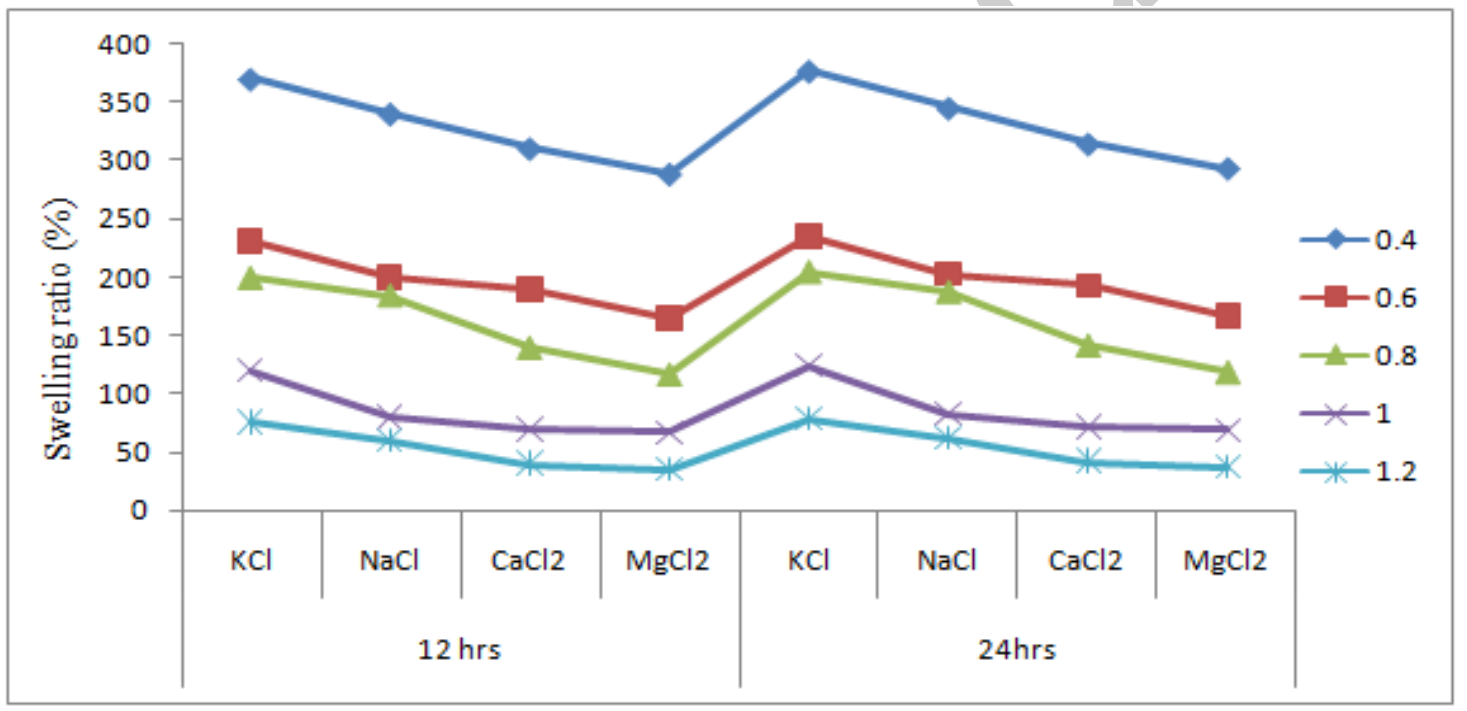

Figure 7. Swelling studies of different concentrated salt solutions at different time. 


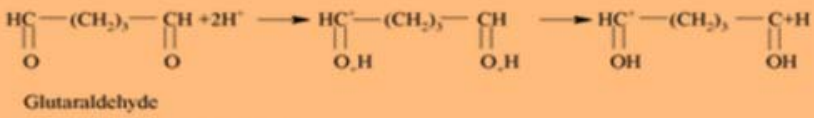

(a) Glutaraldehyde in acid medium

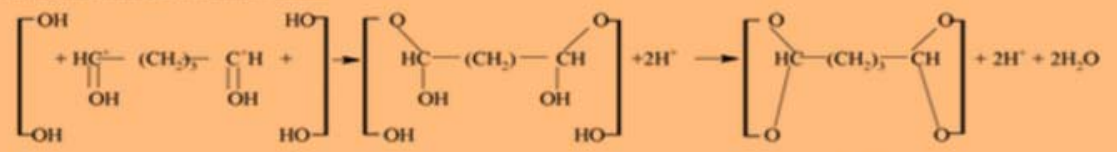

SA

SA
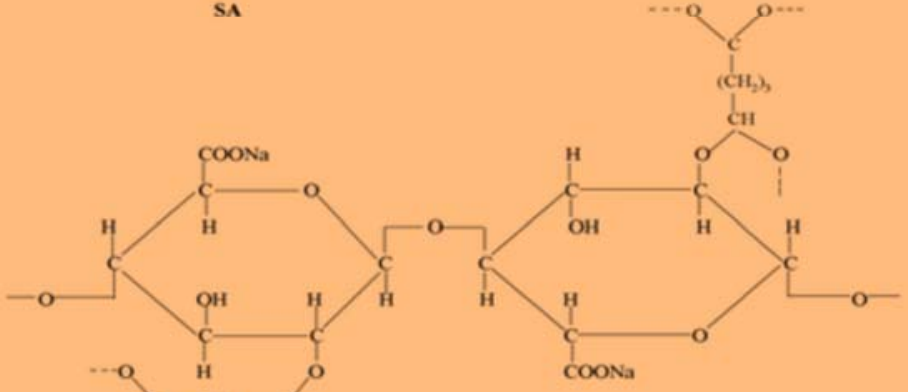

He $\mathrm{H}$ COONa

$=\mathrm{HC}-\left(\mathrm{CH}_{2}\right)_{3}-\mathrm{CH}_{\mathrm{O}}$

(b) Crosslinked Sodium Alginate(SA)

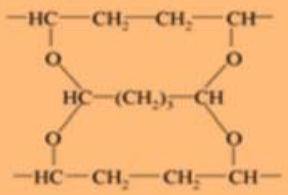

(c) Crosslinked Poly Vinylalcohol (PVA)

Scheme.1

Scheme.1 